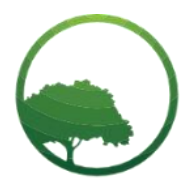

Research in Business \& Social Science

IJRBS VOL 10 NO 6 ISSN: 2147-4478

\title{
A systematic review of corporate governance and ownership
}

\author{
Adetola A. Akinto
}

Department of Business Administration, Faculty of Management, Nile University of Nigeria, Abuja, Nigeria

\author{
ARTICLE INFO \\ Article history: \\ Received 24 August 2021 \\ Received in rev. form 18 Sep. 2021 \\ Accepted 21 Sept 2021 \\ Keywords: \\ Corporate Governance, Ownership, \\ Systematic review \\ JEL Classification: \\ G32; G38
}

\begin{abstract}
A B S T R A C T
This study aims to systematically review the key characteristics and issues of corporate governance and ownership (CGO) research and to offer directional suggestions concerning the future of $C G O$ research. The Systematic Assessment Quantitative Technique (SQAT) was used to identify and analyze 65 peer-reviewed CGO articles from six high-quality academic databases. The study covered 2009 to 2019 and there is evidence of a growing number of CGO articles over the number of years covered. Most of the studies have taken place in Asia and Europe, while South America has the lowest number of studies. $98 \%$ of CGO research has been empirical in nature, which calls for more conceptual studies to give more understanding of the research area because knowledge is dynamic. The primary focus of the articles has been on firm performance and closely followed by regulatory policies. All the CGO articles adopted the quantitative research method, using mainly critical analysis. However, combining both quantitative and qualitative methods will make future studies more robust and give additional insight into various issues of CGO. Finally, the use of only six databases which although contains high quality, peer-reviewed articles, but not all peer-reviewed CGO articles were in the databases. Future systematic reviews can widen the scope of databases to gain further insight.
\end{abstract}

(C) 2021 by the authors. Licensee SSBFNET, Istanbul, Turkey. This article is an open access article distributed under the terms and conditions of the Creative Commons Attribution (CC BY) license (http://creativecommons.org/licenses/by/4.0/).

\section{Introduction}

The erosion of close to $\$ 10$ trillion in market capitalization from global equity markets in October 2008 as a result of Lehman Brothers holdings Inc. demise raised concerns about corporate governance practices (Lioudis, 2019). The Asian Financial Crisis of 1997; the Enron Corporation scandal that led to losses of $\$ 591$ million plus $\$ 628$ million in debt by the end of 2000 and the Global Financial Crisis of 2007 are also prime examples of a financial crisis arguably originating from the firms' financing decisions.

The enormous consequences, namely catastrophic losses of financial firms that almost led to a collapse of the financial system followed by the deep global recession, emphasized the importance of corporate governance (Bajagai et al., 2019). After these financial crises, corporate governance has been undergoing a reform process as the need for effective corporate governance mechanisms becomes more pronounced during troubled periods (Mehdi et al., 2017).

Corporate governance is defined as a set of interrelated mechanisms that has strategic or institutional complementarities to align the conflict of interests between principals and agents; this is dependent on certain combinations, including ownership structure (AlQadasi \& Abidin, 2018). It represents institutional arrangements, decision-making mechanisms, and organizational design (Liu \& Zhang, 2017). Corporate governance is the relationship among shareholders, the board of directors and the top management in determining the direction and performance of a corporation; hence corporate governance variables like board size, board composition, board skills and chief executive officer (CEO)/chair duality may have a direct impact on decisions (Bajagai et al., 2019).

Corporate governance is a framework to build an environment of accountability, trust and transparency (Detthamrong et al., 2017); owing to this, companies will be more transparent and people will have more confidence in them (Tunay \& Yüksel, 2017). Good corporate governance helps companies operate more efficiently, improve access to capital, mitigate risk, and safeguard against mismanagement (International Finance Corporation (IFC), 2019).

* Corresponding author. ORCID ID: 0000-0001-8795-3573

(C) 2021 by the authors. Hosting by SSBFNET. Peer review under responsibility of Center for Strategic Studies in Business and Finance. https://doi.org/10.20525/ijrbs.v10i6.1351 
It is important to note that firms behave differently, depending on the context in which they operate. Laws and Regulations arguably play an important role in shaping the firm's behaviours; without good corporate governance, a country may experience a crisis (Detthamrong et al., 2017).The effectiveness of corporate governance is therefore highly dependent on the national regulatory context (Ducassy \& Guyot, 2017).

A corporate governance framework will typically comprise elements such as legislation, regulation, voluntary commitments, and business practices that are based on a country's specific circumstances such as history and tradition (OECD, 2019); and as new experiences accrue and business circumstances change, the content and structure of this framework may need to be adjusted.

The need for corporate governance (CG) arises from conflict of interest between owners of business and the managers; as a result of Information asymmetries which leads to agency problem between owners and managers (Paniagua et al., 2018) and allows managers to pursue their own agenda that may not be beneficial to the owners. Ownership structure plays a major role in the effectiveness of corporate governance mechanism, where ownership concentration could mitigate or aggravate agency problems that affect governance (AlQadasi \& Abidin, 2018). Beyond this, prior research indicates that corporate decisions, including disclosure choices and strategies, are often decided by corporate boards and owners (Al-Bassam et al., 2018); and shareholder empowerment and shareholder orientation brought about by corporate governance codes take on very different connotations in companies with varying ownership structures (Varottil, 2018).

Existing studies that empirically examine the different extent to which a firm's board and ownership mechanisms can serve as strong or weak antecedents of voluntary compliance and disclosure of good corporate governance practices are generally rare (Al-Bassam et al., 2018); this study will like to examine the available peer reviewed articles on this to give direction for future researches on corporate governance and ownership.

This study aims to carry out a systematic review of corporate governance and ownership structure and identify the gaps. This study is time bound as it uses articles published between 2009 and 2019, and the choice of this timeline is because the research aims to focus on recent developments in the area.

To achieve the aim of this study, two main objectives were set. First, it aimed to identify important characteristics of Corporate Governance and ownership structure researches which are the number of journal articles published; the time and geographic distribution of these articles, the type of articles to know if they are conceptual or empirical, the research themes and theories explored, and the research methods adopted by these articles. Second, it identified gaps in all these areas and attempted to provide suggestions for future research work in these areas.

The rest of the paper has a methodology section, which discusses the method and procedures utilized in conducting this systematic review. Subsequent section discusses the findings of the review and highlights directions for future research based on these findings. Finally, a section which discusses the limitations of the study, and makes recommendations on possible future research based on these findings.

\section{Research \& Methodology}

In conducting this systematic review of Corporate Governance and Ownership, this study adopted the "systematic quantitative assessment technique" (SQAT) developed by Pickering and Byrne (2013). SQAT facilitates the production of reproducible and verifiable reviews, through the identification of "important geographic, scalar, theoretical and methodological gaps in the literature" (Pickering \& Byrne, 2013, p. 11).

SQAT recommends five important steps in conducting an effective systematic review. Each step and how it was applied in this study are described in Table 1. A total of sixty-five peer-reviewed English corporate governance articles met the selection criteria from six academic databases outlined in Table 1. 
Table 1: Description and application of SQAT

\begin{tabular}{|c|c|c|}
\hline & Step & Application in current study \\
\hline 1. & Define topic & Corporate Governance and Ownership \\
\hline 2. & Formulate research questions & $\begin{array}{l}\text { Six research questions: } \\
\text { 1. What is the time distribution of Corporate Governance and Ownership research articles? } \\
\text { 2. In which countries were these articles written? } \\
\text { 3. What kind of Corporate Governance and Ownership articles were published? (Conceptual vs. } \\
\text { Empirical) } \\
\text { 4. What kind of theories were applied in these articles? } \\
\text { 5. What are the specific themes these articles explored, and what were the major findings in each } \\
\text { theme? } \\
6 . \text { What research methods were utilized to conduct the research? }\end{array}$ \\
\hline 3. & Identify key words & "Corporate Governance", "Ownership" \\
\hline 4. & Identify and search databases & $\begin{array}{l}\text { 1. } 6 \text { databases utilized: Elsevier; Emerald, Sage, Springer; Taylor and Francis; Wiley } \\
\text { 2. "All in title" search using two search combinations: } \\
\text { a. "Corporate Governance" + "Ownership" } \\
\text { b. "Ownership Structure" }\end{array}$ \\
\hline 5. & Read and assess publications & $\begin{array}{l}\text { 1. Abstracts of papers found were read to ensure that they were dealing with Corporate Governance } \\
\text { and Ownership } \\
\text { 2. Literature reviews, book chapters and conference proceedings were not included; only peer- } \\
\text { reviewed conceptual and empirical papers. }\end{array}$ \\
\hline
\end{tabular}

\section{Findings}

\section{Time Distribution of CGO Articles}

Based on this study's sample of 65 articles, published between 2009 and 2019, a time distribution analysis was done. The analysis revealed that publishing was fluctuating with the peached reached in 2015 (10 articles). Articles were published each year except for 2019 with the least number of articles was published in 2009, it later picked up as the decade progressed. It should however be noted that articles used for this analysis were downloaded between March and May 2019, it is therefore expected that more articles would have been published thereafter in 2019.

Going by issues surrounding CG, an average number of 4 publications per year reveals that researchers need to do more in the area of publication.

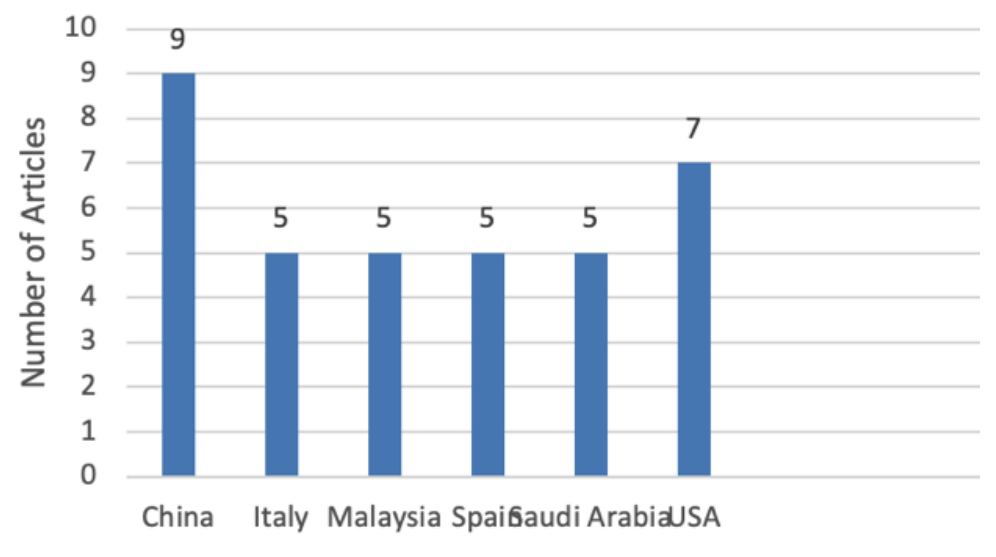

Years

Figure 1: Time distribution of corporate governance and ownership articles 


\section{Geographical Distribution of CGO Articles}

Figure 2 presents the geographical distribution of the 65 CG articles reviewed in this study. 109 Researches were carried out in 44 countries along the six continents.

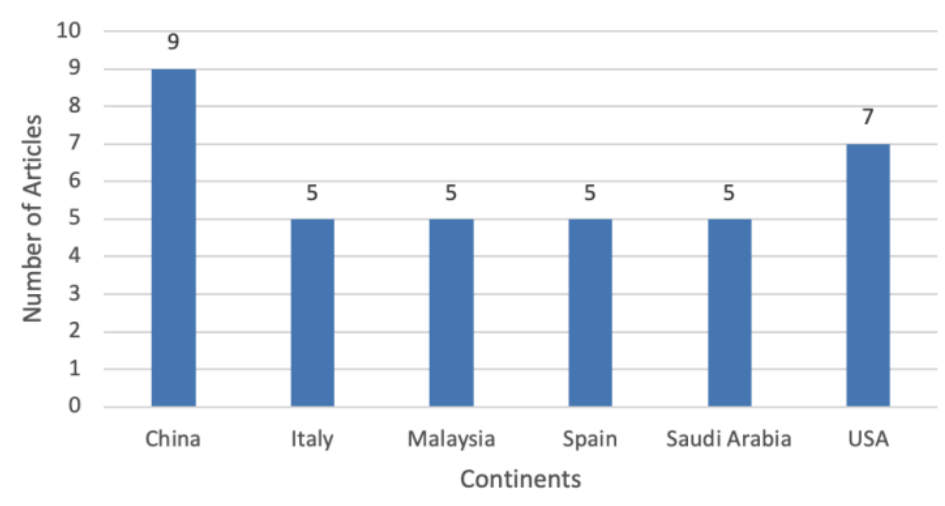

Figure 2: Geographical distribution of CGO articles

It can be observed that Asia has the greatest number of articles published (51), followed by Europe (41), North America (7), Africa (5), Australasia (3), and finally South America (2). South America has the least number of studies in this area, and this reflects a geographical gap in corporate governance research. The high number in Asia and Europe is an indication that ownership is seen as a probable influence on corporate governance in these regions with strong regional unions /cooperation, which allows for easy trade, easy mergers and acquisition, common market, and similar regulations.

From a country perspective, 38 countries were represented in the systematic review of CGO research. Figure 3 represents the top six countries where CGO research was conducted. The analysis shows that China is the country with the highest number of articles (9), followed by USA(7), with Malaysia, Saudi Arabia, Italy and Spain having 5 articles each.

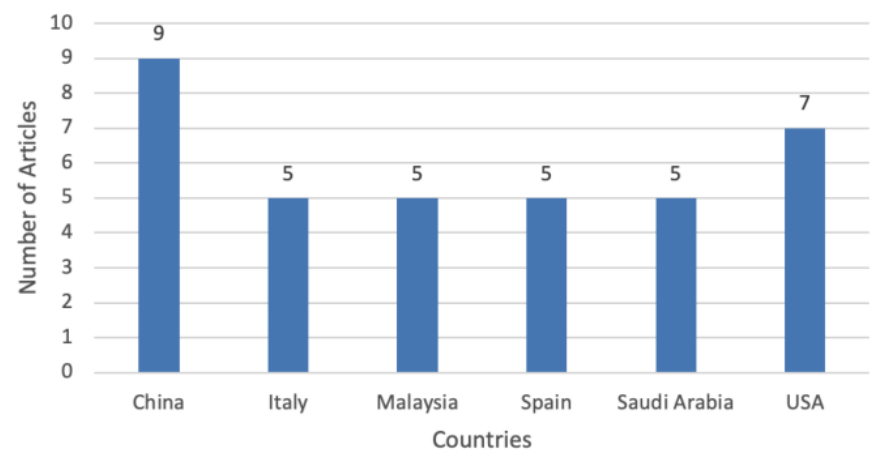

Figure 3: Top 6 countries by research on CGO

Having 38 countries publishing articles on CGO with the highest being 9 is quite low when compared with the total number of countries in the world which is 195 according to worldatlas.com (World map, 2019). Now, considering the influence of majority shareholders on Firms, and the influence of private business owners' especially in family businesses and SMEs, which are currently the focus of a lot of developing countries, one would have loved to see more research carried out on ownership and corporate governance in the developing countries of Africa and part of South America. Even when ownership is separate from management; the principal/agent issue arises, and needs to be researched on.

Although 5 researches were carried out in Africa, 3 were from Ghana. Considering that the issue of Nepotism is rampant in developing countries; also, that integrity and credibility of business are often questioned by international organizations; along with the issue of using of proxy to purchase shares should be good enough reasons for researchers in developing countries of Africa and South America to consider carrying out more research work in this area.

\section{Article Type}

The 65 articles were divided into two categories: conceptual and empirical. Conceptual articles were defined as those that provided a theoretical discussion on CG and ownership whilst empirical articles were those which collected data qualitatively or quantitatively in order to test a particular hypothesis in the real world. Figure 4 presents the breakdown of the 65 articles based on this categorization. 


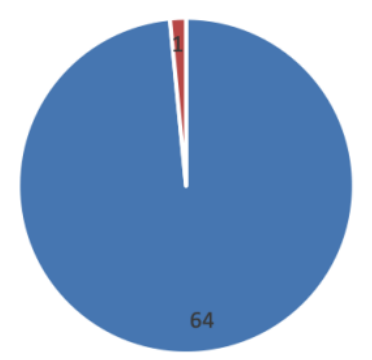

- Empirical (98\%) - Conceptual(2\%)

Figure 4: Article type breakdown

It can be seen from figure 4 that the vast majority of articles reviewed (98\%, 64 out of 65) are empirical in nature, only $2 \%$ of the articles were conceptual in nature $(2 \%, 1$ out of 65$)$. This imbalance represents an obvious gap in CG research which future researchers should address. Although the empirical research work will determine how effective identified strategies are in achieving their important objectives. It was discovered that most of the articles were testing causal relationships or the effect of different types of ownership structure. One could say there is little conceptual work in this area probably because the focus was just on the ownership structure in corporate governance and not the entire corporate governance itself. However, there are many theories that can be examined and propounded in this area because the dynamics of the stock market keeps changing and there is need to know how to bring about improvement in corporate governance as it relates to different ownership issues that might arise from this. Also, new businesses ideas like social entrepreneurship are coming up and there is a need to know how corporate governance will work in such structures. There are also still contending and evolving issues in corporate governance like institutional investors, Principal/Agent relationship and stewardship, that conceptual research will help bring more understanding to. There is need to do more theories to give more understanding on the research area because knowledge is dynamic. The world is ever changing and evolving; carrying out more conceptual work will help bring more knowledge on how to improve on the normative.

\section{Corporate Governance and Ownership Research Themes}

Figure 5 reveals that three CG and Ownership themes were explored by the 65 articles reviewed in this study. Thirty two of the articles (49\%) dealt with Firm performance, which is mainly beneficial to practitioners. Firm performance issues talked about in this category include: The role of ownership structure and the board of directors on IPOs; Do exogenous changes in passive institutional ownership affect corporate governance and firm value; Do corporate governance and ownership structure impact dividend policy in emerging market during financial crisis? Ownership structure, corporate governance and investment efficiency of listed firms.

Corporate governance and firm performance have been found to share a positive relationship with foreign share ownership and board size have been found to have a positive influence on effect on dividend payment in the Ghana Stock Exchange(Bokpin, 2011; Subramanian, 2015). On the other hand however, studies have also shown that there is little evidence that board size, shareholding of CEO, duality of CEO, quality of external auditors and foreign ownership are related to firm earnings (Lai \& Tam, 2017). Foreign banks have been found to be more profitable than domestic banks and managerial ownership said to lead to cost inefficiency of banks Bokpin, 2013).

The second most common theme was Regulatory obligations with twenty five articles (39\%), which is mainly beneficial to Policy Makers. Some of the articles in this category talked about regulatory efforts to enhance transparency and accountability, mandatory disclosure level and voluntary risk disclosure; effective implementation of corporate governance to reduce the effects of government ownership on the implication of the best CG practices and disclosure of quality information. Findings from Lu and Shi, 2012 suggest that government regulations on CG and market completion can serve as complementary solutions to agency problems that arise from state ownership. Al-Bassam, Ntim, Opong and Downs, 2018 are of the opinion that the capacity of corporate governance codes to achieve good governance depends largely on the extent to which managers, owners and firms are willing to engage in effective voluntary compliance and disclosure.

In 2015 a study on the code of corporate governance (CCG) and split share structure reform (SSR) set up in 2002 and 2005 respectively in China. The study revealed that CCG had a positive impact while the SSR had little effect on listed firms' earnings quality (Ji, Ahmed and Lu, 2015). The new regulations set by the Malaysian Government following the 1997 Asian financial crisis was discovered not to have been statistically significant in explaining corporate performance when tested in 2010(Anum, 2010). The time lapse in carrying out these studies is probably a contributing factor in measuring the effectiveness of the regulations; hence studies need to be carried on regularly to measure impact.

While the third theme is Investment decision making with eight articles (12\%) which is beneficial to practitioners. Main discussion around this theme cantered on the relationship between corporate governance and foreign ownership of the banks in developing countries, that the Jordanian institutional investors consider firm capital structure, profitability, business risk, asset structure, asset 
liquidity, growth rates, and firm size when they take their investment decisions (Al-Najjar, 2010). However findings by Subramanian, 2015 indicate that increasing institutional ownership is negatively affecting CG practices of stet-owned firms. According to Opromolla, 2011 lack of disclosure regime could result in misleading information and in turn in a lack of confidence by investors.

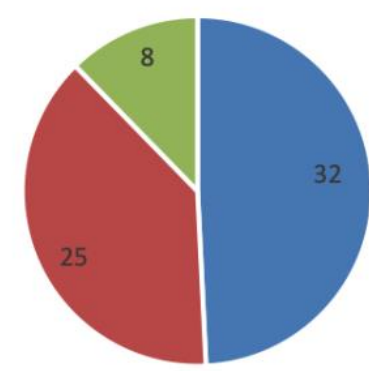

$$
\begin{aligned}
& \text { - Firm Perfromance(49\%) - Regulatory Obligations(39\%) } \\
& \text { = Investment Decision Making(12\%) }
\end{aligned}
$$

Figure 5: CG and ownership themes

\section{Corporate Governance and Ownership Theory breakdown}

In all, thirty-seven different theories on CG and Ownership themes were explored by the 65 articles reviewed in this study. While 20 Journals did not discuss any theory at all, Agency theory was the most discussed in thirty-six articles. Twenty-six other theories were discussed in just an article each. Figure 6 shows the top eleven theories that were reviewed in the downloaded 65 journal articles.

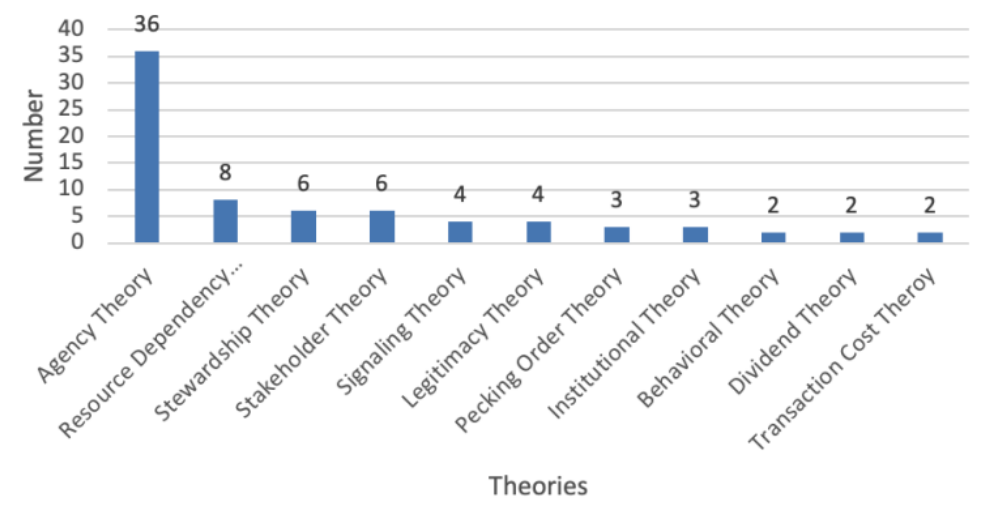

Figure 6: Theory breakdown

\section{Research Methods}

In this section, the objective was to identify the primary research method utilized in each of the 64 empirical CG and Ownership articles reviewed in this study. Figure 7 provides a summary of the findings with only quantitative method used by all the researchers. 61 of the quantitative method were via content analysis while just 3 were through survey. Although the parameters and sample size involved in the study might have made using quantitative method most appropriate; however the use of qualitative method or combining both quantitative and qualitative method will make the study more robust and well rounded. Using qualitative method will allow respondents to give their opinions because CG involves other stakeholders like employees, the community, and by not just using available records or passing out questionnaires but using interviews or by observation, will help researchers to know whether CG codes are being applied and whether business owners' influence is affecting adherence to CG codes set by sectors of the economy or the jurisdictions. 


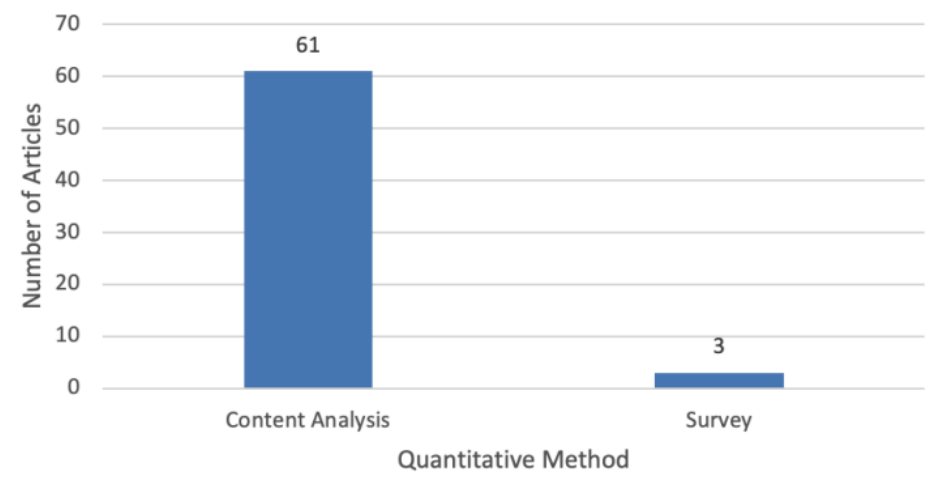

Figure 7: Research method breakdown

\section{Conclusion}

This paper reviewed 65 peer-reviewed journal articles dealing with Corporate Governance and Ownership These articles were examined along six key categories, including the time distribution of the articles, geographical distribution of the article, article type, research themes, theories reviewed and research methods. The results of the review were discussed and directions for future research were provided. Although a lot of research has been carried out in this area, there is still need for more especially in developing countries. Most research works were empirical, so more conceptual work need to be carried out.

This study is important as it provides a clear picture on the current state of CG and ownership research and gives clear direction on the areas that future research needs to address in order to create a more transparent and credible institutions.

Some limitations exist in this study; these limitations are gaps future CGO research can explore. The first limitation is that this study is time bound, only articles published in 2009 to 2019 were used.

Another limitation is the use of six databases. Although, these databases contain high quality, peer-reviewed articles, but not all peerreviewed CGO articles were in the databases. Future systematic reviews can widen the scope of databases to gain further insight.

The third limitation is that book chapters and conference proceeding were excluded. This was done in accordance with the SQAT methodology to maintain the high quality of articles reviewed. There are however potentially very useful insight in book chapters and conference proceedings, that future research would do well to include.

The use of title word search instead of a key word search is another limitation. While a title word search provides a more precise search of articles that are dealing with CGO; however, a key word search would have provided a larger number of articles for the review that would have given useful insight.

In spite of these limitations, this study has been able to provide insight on the current state of CGO research and direction on the areas that future research needs to address.

\section{References}

Aguilera, R. V., \& Crespi-Cladera, R. (2016). Global corporate governance: On the relevance of firms' ownership structure. Journal of World Business, 51(1), 50-57. https://doi.org/10.1016/j.jwb.2015.10.003

Al-Bassam, W. M., Ntim, C. G., Opong, K. K., \& Downs, Y. (2018). Corporate boards and ownership structure as antecedents of corporate governance disclosure in Saudi Arabian publicly listed corporations. Business \& Society, 57(2), 335-377. https://doi.org/10.1177/0007650315610611

Al-Janadi, Y., Abdul Rahman, R., \& Alazzani, A. (2016). Does government ownership affect corporate governance and corporate disclosure? Evidence from Saudi Arabia. Managerial Auditing Journal, 31(8/9), 871-890. https://doi.org/10.1108/MAJ-122015-1287

Al-Najjar, B. (2010). Corporate governance and institutional ownership: evidence from Jordan. Corporate Governance: The international journal of business in society, 10(2), 176-190. https://doi.org/10.1108/14720701011035693

AlQadasi, A., \& Abidin, S. (2018). The effectiveness of internal corporate governance and audit

quality: the role of ownership concentration-Malaysian evidence. Corporate Governance: The International Journal of Business in Society, 18(2), 233-253. https://doi.org/10.1108/CG-02-2017-0043

Alvarez-Otero, S., \& Lopez-Iturriaga, F. J. (2018). Does corporate governance affect the valuation of Spanish IPOs? The role of ownership structure and the board of directors. Spanish Journal of Finance and Accounting/Revista Española de Financiación y Contabilidad, 47(2), 214-241. https://doi.org/10.1080/02102412.2018.1429556

Anum Mohd Ghazali, N. (2010). Ownership structure, corporate governance and corporate performance in Malaysia. International Journal of Commerce and Management, 20(2), 109-119. https://doi.org/10.1108/10569211011057245 
Bajagai, R. K., Keshari, R. K., Bhetwal, P., Sah, R. S., \& Jha, R. N. (2019). Impact of Ownership Structure and Corporate Governance on Capital Structure of Nepalese Listed Companies. In Business Governance and Society (pp. 399-419). Palgrave Macmillan, Cham. https://doi.org/10.1007/978-3-319-94613-9_22

Bekiris, F. V. (2013). Ownership structure and board structure: are corporate governance mechanisms interrelated?. Corporate Governance: The international journal of business in society, 13(4), 352-364. https://doi.org/10.1108/CG-02-2011-0013

Bokpin, G. A. (2011). Ownership structure, corporate governance and dividend performance on the Ghana Stock Exchange. Journal of Applied Accounting Research, 12(1), 61-73. https://doi.org/10.1108/09675421111130612

Bokpin, G. A. (2013). Ownership structure, corporate governance and bank efficiency: an empirical analysis of panel data from the banking industry in Ghana. Corporate Governance: The international journal of business in society, 13(3), $274-287$. https://doi.org/10.1108/CG-05-2010-0041

Bokpin, G. A., Isshaq, Z., \& Aboagye-Otchere, F. (2011). Ownership structure, corporate governance and corporate liquidity policy: Evidence from the Ghana Stock Exchange. Journal of Financial Economic Policy, 3(3), 262-279. https://doi.org/10.1108/17576381111152236

Borisova, G., Brockman, P., Salas, J. M., \& Zagorchev, A. (2012). Government ownership and corporate governance: Evidence from the EU. Journal of Banking \& Finance, 36(11), 2917-2934. https://doi.org/10.1016/j.jbankfin.2012.01.008

Carrillo, G., \& Bathala, C. (2010). Corporate Governance in Banks: Do Ownership and Board Structure Matter for Banks' Risk Profile and Valuation? Indian Journal of Corporate Governance, 3(1), 1-18. https://doi.org/10.1177/0974686220100101

Chen, C. (2013). Discussion of 'Government ownership, corporate governance and tax aggressiveness: evidence from China'. Accounting \& Finance, 53(4), 1053-1059. https://doi.org/10.1111/acfi.12054

Chen, N., Sung, H. C., \& Yang, J. (2017). Ownership structure, corporate governance and investment efficiency of Chinese listed firms. Pacific Accounting Review, 29(3), 266-282. https://doi.org/10.1108/PAR-12-2015-0046

Cho, K. R., Huang, C. H., \& Padmanabhan, P. (2014). Foreign ownership mode, executive compensation structure, and corporate governance: Has the literature missed an important link? Evidence from Taiwanese firms. International Business Review, 23(2), 371-380. https://doi.org/10.1016/j.ibusrev.2013.06.005

Connelly, B. L., Hoskisson, R. E., Tihanyi, L., \& Certo, S. T. (2010). Ownership as a form of Corporate governance. Journal of management studies, 47(8), 1561-1589. https://doi.org/10.1111/j.1467-6486.2010.00929.x

Connelly, J. T., Limpaphayom, P., \& Nagarajan, N. J. (2012). Form versus substance: The effect of ownership structure and corporate governance on firm value in Thailand. Journal of Banking \& Finance, 36(6), $1722-1743$. https://doi.org/10.1016/j.jbankfin.2012.01.017

Cueto, D. C., \& Switzer, L. N. (2015). Intraday market liquidity, corporate governance, and ownership structure in markets with weak shareholder protection: evidence from Brazil and Chile. Journal of Management \& Governance, 19(2), 395-419. https://doi.org/10.1007/s10997-013-9263-8

Darko, J., Aribi, Z. A., \& Uzonwanne, G. C. (2016). Corporate governance: the impact of director and board structure, ownership structure and corporate control on the performance of listed companies on the Ghana stock exchange. Corporate Governance, 16(2), 259-277. https://doi.org/10.1108/CG-11-2014-0133

Deb, S., \& Dube, I. (2017). Corporate Governance Disclosure for Complex Ownership Structure in India. Indian Journal of Corporate Governance, 10(2), 143-175. https://doi.org/10.1177/0974686217730937

Detthamrong, U., Chancharat, N., \& Vithessonthi, C. (2017). Corporate governance, capital structure and firm performance: evidence from Thailand. Research in International Business and Finance, 42, 689-709. https://doi.org/10.1016/j.ribaf.2017.07.011

Ducassy, I., \& Guyot, A. (2017). Complex ownership structures, corporate governance and firm performance: The French context. Research in International Business and Finance, 39, 291-306. https://doi.org/10.1016/j.ribaf.2016.07.019

Goldberg, S. R., Danko, D., \& Kessler, L. L. (2016). Ownership structure, fraud, and Corporate governance. Journal of Corporate Accounting \& Finance, 27(2), 39-46. https://doi.org/10.1002/jcaf.22120

Grassa, R. (2018). Deposits structure, ownership concentration and corporate governance disclosure in GCC Islamic banks: Empirical evidence. Journal of Islamic Accounting and Business Research, 9(4), 587-606. https://doi.org/10.1108/JIABR10-2014-0034

Henry, D. (2010). Agency costs, ownership structure and corporate governance compliance: A private contracting perspective. Pacific-Basin Finance Journal, 18(1), 24-46. https://doi.org/10.1016/j.pacfin.2009.05.004

Hernández-Cánovas, G., Mínguez-Vera, A., \& Sánchez-Vidal, J. (2016). Ownership structure and debt as corporate governance mechanisms: an empirical analysis for Spanish SMEs. Journal of Business Economics and Management, 17(6), 960-976. https://doi.org/10.3846/16111699.2013.859171

Holm, C., \& Schøler, F. (2010). Reduction of asymmetric information through corporate governance mechanisms-the importance of ownership dispersion and exposure toward the international capital market. Corporate Governance: An International Review, 18(1), 32-47. https://doi.org/10.1111/j.1467-8683.2009.00777.x

Huang, Y., Chen, A., \& Kao, L. (2012). Corporate governance in Taiwan: The nonmonotonic relationship between family ownership and dividend policy. Asia Pacific Journal of Management, 29(1), 39-58. https://doi.org/10.1007/s10490-011-9279-z

Ji, X., Ahmed, K., \& Lu, W. (2015). The impact of corporate governance and ownership structure reforms on earnings quality in China. International Journal of Accounting \& Information Management, 23(2), 169-198. https://doi.org/10.1108/IJAIM-052014-0035 
Kumar, P., \& Zattoni, A. (2015). Ownership structure, corporate governance and firm performance. Corporate Governance: An International Review, 23(6), 469-471. https://doi.org/10.1111/corg.12146

Lai, L., \& Tam, H. (2017). Corporate governance, ownership structure and managing earnings to meet critical thresholds among Chinese listed firms. Review of Quantitative Finance and Accounting, 48(3), 789-818. https://doi.org/10.1007/s11156-0160568 -y

Lim, M., How, J., \& Verhoeven, P. (2014). Corporate ownership, corporate governance reform and timeliness of earnings: Malaysian evidence. Journal of Contemporary Accounting \& Economics, 10(1), 32-45. https://doi.org/10.1016/j.jcae.2013.11.001

Lioudis, N. (2019) The Collapse of Lehman Brothers: A Case Study. Retrieved from https://www.investopedia.com

Liu, L., Qu, W., \& Haman, J. (2018). Product market competition, state-ownership, corporate governance and firm performance. Asian Review of Accounting, 26(1), 62-83. https://doi.org/10.1016/j.jcae.2013.11.001

Liu, X., \& Zhang, C. (2017). Corporate governance, social responsibility information disclosure, and enterprise value in China. Journal of Cleaner Production, 142, 1075-1084. https://doi.org/10.1016/j.jclepro.2016.09.102

Lozano, M. B., Martínez, B., \& Pindado, J. (2016). Corporate governance, ownership and firm value: Drivers of ownership as a good corporate governance mechanism. International Business Review, 25(6), 1333-1343. https://doi.org/10.1016/j.jclepro.2016.09.102

Lu, Y., \& Shi, X. (2012). Corporate governance reform and state ownership: Evidence from China. Asia-Pacific Journal of Financial Studies, 41(6), 665-685. https://doi.org/10.1111/ajfs.12001

Mehdi, M., Sahut, J. M., \& Teulon, F. (2017). Do corporate governance and ownership structure impact dividend policy in emerging market during financial crisis?. Journal of applied accounting research, 18(3), 274-297. https://doi.org/10.1108/JAAR-072014-0079

Mishra, S. P., \& Srivatsava, H. V. (2010). Corporate Governance: An empirical Analysis of Ownership and Performance in Indian banks. Indian Journal of Corporate Governance, 3(1), 19-36. https://doi.org/10.1177/0974686220100102

Mollah, S., Al Farooque, O., \& Karim, W. (2012). Ownership structure, corporate governance and firm performance: Evidence from an African emerging market. Studies in Economics and Finance, 29(4), 301-319. https://doi.org/10.1108/10867371211266937

OECD Corporate Governance Factbook (2019). Organization for Economic Co-operation and Development, Paris.

Opromolla, G. (2011). Corporate ownership interests hidden through cash-settled equity derivatives: impact on the companies' governance under the Italian legal framework. Journal of Investment Compliance, 12(1), 30-34. https://doi.org/10.1108/15285811111122029

Paniagua, J., Rivelles, R., \& Sapena, J. (2018). Corporate governance and financial performance: The role of ownership and board structure. Journal of Business Research, 89, 229-234. https://doi.org/10.1016/j.jbusres.2018.01.060

Pergola, T. M., \& Joseph, G. W. (2011). Corporate governance and board equity ownership. Corporate Governance: The international journal of business in society, 11(2), 200-213. https://doi.org/10.1108/14720701111121065

Reddy, K., \& Locke, S. (2014). The relationship between ownership structure, capital structure and Corporate governance practices: A case study of co-operatives and mutuals in New Zealand. International Journal of Managerial Finance, 10(4), 511-536. https://doi.org/10.1108/IJMF-12-2012-0130

Roy, A. (2015). Dividend policy, ownership structure and corporate governance: An empirical analysis of Indian firms. Indian Journal of Corporate Governance, 8(1), 1-33. https://doi.org/10.1177/0974686215574422

Said Mokhtar, E., \& Mellett, H. (2013). Competition, corporate governance, ownership structure and risk reporting. Managerial Auditing Journal, 28(9), 838-865. https://doi.org/10.1108/MAJ-11-2012-0776

Schmidt, C., \& Fahlenbrach, R. (2017). Do exogenous changes in passive institutional ownership affect corporate governance and firm value?. Journal of Financial Economics, 124(2), 285-306. https://doi.org/10.1016/j.jfineco.2017.01.005

Segal, T. (2019). Enron Scandal: The Fall of a Wall Street Darling. Retrieved from https:// www.investopedia.com

Shapiro, D., Tang, Y., Wang, M., \& Zhang, W. (2015). The effects of corporate governance and ownership on the innovation performance of Chinese SMEs. Journal of Chinese Economic and Business Studies, 13(4), $311-335$. https://doi.org/10.1080/14765284.2015.1090267

$\mathrm{Su}, \mathrm{D} .$, \& He, X. (2012). Ownership structure, corporate governance and productive efficiency in China. Journal of productivity analysis, 38(3), 303-318. https://doi.org/10.1007/s11123-011-0257-8

Subramanian, S. (2015). Corporate governance, institutional ownership and firm performance in Indian state- owned enterprises. Asia-Pacific Journal of Management Research and Innovation, 11(2), 117-127. https://doi.org/10.1177/2319510X15576273

Tunay, K. B., \& Yüksel, S. (2017). The relationship between corporate governance and foreign ownership of the banks in developing countries. Contaduría y administración, 62(5), 1627-1642. https://doi.org/10.1016/j.cya.2017.05.007

Utama, C. A., Utama, S., \& Amarullah, F. (2017). Corporate governance and ownership structure: Indonesia evidence. Corporate Governance: The international journal of business in society, 17(2), 165-191. https://doi.org/10.1108/CG-12-2015-0171

Varottil, U. (2018). Proliferation of corporate governance codes in the backdrop of divergent ownership structures. Competition \& Change, 1024529418813832. https://doi.org/10.1177/1024529418813832

World Map (2019), available at: http://www.worldatlas.com/nations.html 
Yoshikawa, T., Zhu, H., \& Wang, P. (2014). National governance system, corporate ownership, and roles of outside directors: A corporate governance bundle perspective. Corporate Governance: An International Review, 22(3), 252-265. https://doi.org/10.1111/corg.12050

Zambarloukou, S. (2010). Ownership, corporate governance and industrial relations in the banking and telecommunications sectors: the case of Greece. Industrial Relations Journal, 41(3), 233-248. https://doi.org/10.1111/j.1468-2338.2010.00566.x

Publisher's Note: SSBFNET stays neutral with regard to jurisdictional claims in published maps and institutional affiliations.

\section{(a) (1)}

(c) 2021 by the authors. Licensee SSBFNET, Istanbul, Turkey. This article is an open access article distributed under the terms and conditions of the Creative Commons Attribution (CC BY) license (http://creativecommons.org/licenses/by/4.0/).

International Journal of Research in Business and Social Science (2147-4478) by SSBFNET is licensed under a Creative Commons Attribution 4.0 International License. 